\title{
Geochemistry and coal quality of Ovootkhural depression in South Mongolia
}

OCHIRBAT $\mathrm{M}^{1}$, SELENGEE $\mathrm{O}^{2}$, JARGALAN $\mathrm{S}^{1}$

${ }^{1}$ Mongolian University of Science and Technology

Ochiroo_sg@yahoo.com,jargalan@edu.mn

${ }^{2}$ Golden hill LLC selengegeo@gmail.com

Mongolia has abundant resources of coal and it accounts about 150 billion tons. Coal deposition in Mongolia was occurred at 4 main different geological periods: Carboniferous, Permian, Jurassic and Cretaceous. Ovoot khural coal depression is located in southern Mongolia. Totally, 16 deposits formed throughout OvootKhural coal bearing depression structure, which stretches for over $100 \mathrm{~km}$ with a width $20 \mathrm{~km}$. Coal-bearing sediments developed in an intermountain basin during the Lower-middle Jurassic age. Coal seams formed monoclonal structure with dip from 25 to 80 degrees to southwards. There are 9 coal seams in coal bearing sediment which is approximately $350 \mathrm{~m}$ thick. Carbon and hydrogen ratio is $15.3-18.3 \%$, on in average $16.5 \%$, which shows that is a hard coal. In the Western and Central parts of the depression, carbon content in anthracite is $88-96 \%$. The feature of coal seams of the Ovoot khural depression is Gashuu tolgoi and Huvd deposit, which are located in west part have low sulfur, while Sunset located in Central part has low rate of ash, but Sumber located in east part has lowest volatile. Forms of sulfur analysis shows on an average that $40 \%$ organic sulfur, $32 \%$ sulphidic sulfur and $27.5 \%$ sulphate sulfur, respectively. Classified the coal bearing sandstone facies as with some lithic arkose and fieldspartic litharenite indicating that they are slightly mineralogically mature. (Folk. 1974) These samples plot in the recycled orogeny field in the tectonic discrimination diagram of Dickinson (1985). Qm-F-Lt triangular plots (Dickinson, 1985) indicate that two samples plot in the mixed, two samples in the Dissected arc and one sample Quartzose Recycled. Floyd \& Leveridge (1987) established a discrimination diagram using the $\mathrm{La} / \mathrm{Th}$ ratio $\mathrm{v}$. Hf to determine active continential margine. 
This abstract is too long to be accepted for publication.

Please revise it so that it fits into the column on one page. 